\title{
Factors Affecting the Effectiveness of Remedial Work Policy In Selected Secondary Schools In Kasempa District
}

\author{
Lastone Musongole \& Ferdinand M. Chipindi \\ University of Zambia
}

\begin{abstract}
The study aimed to explore the factors affecting the effectiveness of remedial work policy in selected secondary schools in the Kasempa District of North-Western Province of Zambia. Despite the existence of localised corrective work policy in schools and the emphasis on the need for sustained remedial work, academic achievement remained low in secondary schools of Kasempa District. This is as evidenced by results in the National Examinations at grades 9 and 12 levels. We used a descriptive case study design to collect and analyse the data. The factors explored were government and school policies on remedial work, teacher preparedness and ability to prepare various teaching/learning activities, and the head teacher characteristics and support to remedial work. On the other hand, external factors explored included parental monitoring of learners' schoolwork, parental guidance and checking on homework, home environment and parental support to learners' education. The study recommends that similar studies be conducted throughout the country.
\end{abstract}

\section{INTRODUCTION}

$\mathrm{R}$ emedial work is a form of cooperative and supportive learning between teachers and learners. It is intended to help learners who fall behind grasping lessons during average learning time (Shield \& Morgan, 1998). Arising from this definition, it follows that carrying out remedial work emanates from the teacher's understanding of the learners' low capability to learn. The teacher will have noted that the learners being handled in a subject are not exhibiting the desired and expected learning outcomes, as dictated by the curriculum and syllabus. Teachers have a responsibility to help identified slow learners who fail to comprehend lessons during regular time-tabled classes. As such, teachers frequently employ remedial work to achieve teaching/learning goals. For this reason, restorative work is also referred to as supplementary teaching (Shield \& Morgan, 1998; Moonga et al., 2018).

According to some research findings (Swarup-Mehta, 2011), remedial teaching leads to remarkable positive changes in cognitive and thinking abilities even after a short period of three months. It has also been recognised that Phonological and Reading Remediation programmes improve learner ability (Silva \&Capellium, 2010). Both Swarup-Mehta (2011) and Silva \&Capellium (2010) asserted that remediation improves perception, production and manipulation of sounds and syllables by learners, which directly interferes with the reading skills comprehension of learning materials by learners. Studies have shown that instructional quality determines learners' academic achievement (Levpuscek \& Zupancic, 2009) and that learner-centred instruction resulted in higher learner academic achievement than lecture methods (McEwin \& Greene, 2010; Manchishi \& Hamweete, 2017).

An educational system's quality and effectiveness depend in part on the quality of instructions offered by teachers to meet the system's goals (MoE, 1996). Zambia has implemented several educational reforms since independence to enhance the delivery of quality education in the country. The national curriculum's recent adjustments at various learning levels are contained in the Zambia Education Curriculum Framework of 2013 (Ministry of Education, Science, Vocational Training and Early Education [MESVTEE], 2013). All learners are in school as unique individuals. There are fast learners and slow learners. All learners found to be underachieving must be given remedial work. Schools with well-coordinated remedial work score higher pass rates than those that do not. Therefore, teachers have a responsibility to ensure that all categories of learners score expected academic achievement. So slow learners must receive remedial teaching to reduce drop-out rates and improve the education system's effectiveness. Hence the government, through the 2013 Zambia Education Curriculum Framework, sought to introduce and implement remedial work

\subsection{Statement of the Problem}

Although many factors may affect learner academic achievement, remedial work is meant to improve schools' performance. However, five years into the implementation of the new Zambia Education Curriculum Framework, with every school claiming to carry out remedial work, the results at Grades 9 and 12 in National Examinations in Kasempa District have remained dismal. This is despite the many frantic efforts and expenses by the ministry of education. This research, therefore, sought to unearth and explore the factors that affect the effectiveness of remedial work policy in the selected secondary schools in Kasempa. Teachers' methods and teaching activities in remedial work in selected secondary schools in Kasempa District are not documented. Researchers have focussed on other dimensions of the research enterprise 
(Chipindi, 2017; Chipindi \& Chipindi, 2016; Thomas, Serenje-Chipindi, \& Chipindi, 2020), hence the current study.

\section{3. $\quad$ Research Objectives}

i. To explore the strategies employed in implementing the remedial work policy in selected secondary schools in Kasempa District.

ii. To identify the underlying factors affecting remedial work policy implementation in selected secondary schools in Kasempa District.

iii. To establish the challenges faced in the implementation of remedial work in selected secondary schools in Kasempa District.

\subsection{Significance of the Study}

The findings could help teachers to improve how to carry out remedial work better and improve their effectiveness. Specific challenges brought out in the results could help the schools, parents, communities, government, and other stakeholders identify areas where they should render help and improve remedial work effectiveness. The research results could also serve as the basis for the formulation of school local policies meant to strengthen learner academic achievement. The study could also provide a platform for further research to improve remedial work effectiveness in schools.

\section{LITERATURE REVIEW}

Many studies have been done to investigate remedial work in schools, and these studies provide a great backbone on which this study will add some flesh. The gaps in the research work, however, necessitate this study. This section, therefore, reviews some literature relevant to effectiveness in the implementation of remedial work policy in secondary schools. It undertakes both empirical and theoretical reviews.

In the study of the use of remedial work in Map Skills in Geography among learners by Chikwature and Oyedele (2016), it was established that remediation was crucial in teaching and learning map work other topics or subject and improved the performance of students. Whereas it is shown that remediation work on Map Skills in Geography improved pupils' performance, factors that affect the effectiveness of remedial work in secondary schools are not explored by the study. The teachers' input regarding factors impacting remedial work's efficacy would also need to be explored through a study like this one as conducted in some selected secondary schools of Kasempa District.

Sociological research in education such as that of Douglas (1964) and the Plowden Report (1967), commissioned a study on educational influences, have shown that the school is by no means the sole educator of the child, or by any means the significant impact on the child's life. Of great importance is the influence of the home. Several reports in England also drew attention to the potential of collaboration between professionals and parents to children's development and learning (Her Majesty's Stationary Office [HMSO], 1967;
Bullock, 1975; HMSO 1977; \&Warnock, 1978; MwaleMkandawire, 2019; Mukalula, 2015; Msango et al., 2015). These reports covered many aspects of collaboration between teachers and parents in the educational field. Further exploration in the dimensions and potential of home-school links was shown by Smith (1987).It is the belief among many educators that parents must be involved in their children's education, which could lead to successful learning achievements when parents are willing to help. Research by Hewison (1982) has indicated that parents are generally actively interested in their children's development and educational progress.

Dr Roger Morgan, who pioneered the Paired Reading approach, proposed to develop a flexible reading technique that was both attractive and useful to tutors and learners alike, which would enhance reading performance. Morgan outlines the steps involved in this technique and explains the rationale behind it. First, Morgan (1989), tuition is usually undertaken, by the individual parent/child pairs at home, using a book of the child's choice, appropriate to their reading age. These sessions are initiated with the parent and the child reading aloud simultaneously, the parent providing a continuous prompt or model for the child's reading. He signals this by knocking on the table to achieve a significant proficiency in reading and confidence for the child to start reading new words or entire passages independently. The parent responds by praising the child, then stops reading with the child, and continues reading alone. When the child reads alone correctly, the parent reinforces the correct reading with frequent praise or feedback through positive comments suitable for the individual learner. When the child encounters difficult words or makes errors during independent reading, the parent allows approximately four seconds for further attempts. Suppose the child is unable to resolve the difficulty within this set time limit. In that case, the parent supplies the correct reading, the child reads it with the parent, and the simultaneous task is resumed (Educational Review, 1994; Daka et al., 2017a; Daka et al., 2017b; Daka, 2019).

Given the above analysis of data, it is clear from the onset that the study's context is different. This contextual difference renders the results inapplicable as far as a generalisation to the Zambian set-up is concerned. This is because the educational system, staffing, policies and practices, among many other factors, differ. Secondly, the differences in methodologies are also apparent none of these studies takes up a multistakeholder approach. Additionally, no study has ever been published that evaluates the current policy and practice on factors affecting the effectiveness of remedial work policy in selected secondary schools in Kasempa District. This research, therefore, bridges the contextual, methodological and information gaps discussed here. The next chapter presented the methodology of this study. 


\section{METHODOLOGY}

The validity and reliability of any research have their foundation in the research methodology. This section explains the research methodology employed in this research.

\subsection{Research Design}

This research employed a case study approach that involved selecting secondary schools in Kasempa District in North Western Province. The case study must involve a limited number of analysis units, such as an individual, a group, or an institution studied intensively (Welman and Kruger, 2002, Chipindi, 2018; Mukalula). In a case study, the researcher must explore various procedures to collect a single entity or phenomenon bound by time and activity and data during a sustained period (Mirriam, 1988, Daka, Chipindi and Mkandawire, 2020; Mukalula, 2020; Mpolomoka et al., 2016; Chipindi \& Vavrus, 2018).

\subsection{Population and Sample}

The study involved exploring factors that affected remedial work effectiveness in Kasempa District of North Western Province. To effectively do so, a selection of secondary schools in the Kasempa District of North Western Province was made using the purposive sampling method. Five secondary schools were selected from which teachers, pupils, parents and administrators were sampled. Six teachers, six pupils, six parents, and two administrators were chosen from each of the five schools. Therefore, 30 teachers, 30 pupils, 30 parents and ten administrators were chosen with three key informants found at the Debs office. Thus, we had a total of 103 research participants.

\subsection{Research Instruments}

The study used multiple sources of data, and the underlying principle behind this was that various sources of evidence offered the opportunity to address a broader range of issues. Notwithstanding this, the most significant advantage presented using multiple sources of evidence is the "development of converging lines of inquiry," increasing the validity, quality, and reliability of the findings (Yin, 2003). Further, we achieved reliability and validity of data collected from the field through conducting a pilot study in the research area to reveal weaknesses in the data collection instruments. A pilot study was done in early May to accord the opportunity to take note of the recent trends in the general way of life in the study areas.

\subsubsection{Semi-Structured Questionnaire/Interview}

This questionnaire uses both structured and unstructured questions and, therefore, uses both closed and open questions. We administered a semi-structured questionnaire to the teachers as a self-administer questionnaire.

\subsubsection{Semi-Structured Interview guide}

For the school administrators and government officials, a set of pre-planned core questions were prepared for guidance such that the same areas were covered with each interviewee. (Cohen et al., 2000 \& Chipindi and Doyle, 2017; Hambulo \& Mukalula, 2017). This method also ensured the validity of responses as I could clarify some questions that the participants had not understood.

\subsubsection{Focus Group Discussions}

Focus group interview is less structured compared to the other categories of interviews. This is because of the difficulty in bringing structure in a group; however, rich data can emerge through interaction within the group; for example, sensitive issues that could have been missed in individual interviews may be revealed. In a group, people develop and express ideas they would not have thought about on their own (Preece et al., 2002).This instrument's use allowed for the generation of varied responses from the study area participants than those anticipated by the researcher in interview schedules. It also allowed for in-field data correction as participants in the groups would correct inappropriate responses by their peers or colleagues.

\subsubsection{Ethical Considerations}

Before going into the field to collect data, permission was sought from the University of Zambia/Zimbabwe Open University (UNZA/ZOU). Then permission was also sought from the District Education Board Secretary (DEBS) in Kasempa to allow the researchers to collect data from the participating schools. A letter introducing the researcher to the school headteachers was obtained from DEBS. Respondents signed a consent form for each participating category of teachers and parents before participating in the study. The data collected from the field was treated with the highest confidentiality level possible, getting respondents' actual responses. The collected data was treated with due confidentiality and was used strictly for academic purposes only. Names of all participants have not been disclosed in any way to maintain strict confidentiality.

\section{FINDINGS AND DISCUSSION}

\section{Implementation Strategies}

Teachers were asked whether they were aware of remedial strategies, and the following chart tabulates the responses.

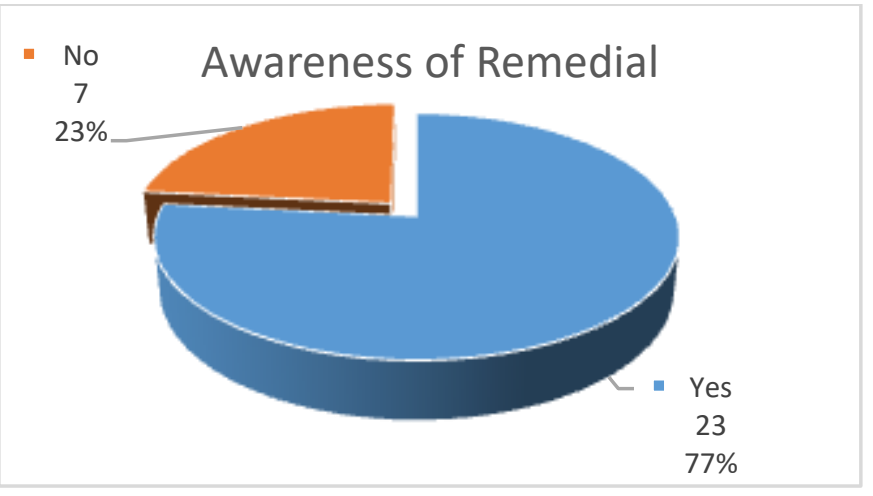

Figure 1: Awareness of Remedial Strategies 
As shown in figure 3 above, most $(77 \%)$ were aware of remedial strategies, while the minority $(23 \%)$ are not aware of them. However, the high percentage of teachers who were not aware of was alarming and might result in poor implementation.

A follow-up question was posed to those who were aware of who they believed was responsible for remedial policy implementation in general, and the table below shows the outcome.

Table 1: Teacher's Perception of rights Implementer

\begin{tabular}{|c|c|c|c|c|c|c|}
\hline Responsibility & & & & & & \\
\hline & Ministry & School & Teacher & PTA & Parent & Pupil \\
\hline Yes & 13 & 12 & 17 & 7 & 10 & 7 \\
\hline No & 9 & 10 & 5 & 15 & 12 & 15 \\
\hline Total & 22 & 22 & 22 & 22 & 22 & 22 \\
\hline
\end{tabular}

Table 12 above shows that the respondents believe that implementing the policy lies predominantly with the teacher, followed by the ministry and the school, respectively. The PTA and the pupils are the least responsible, followed by parents.

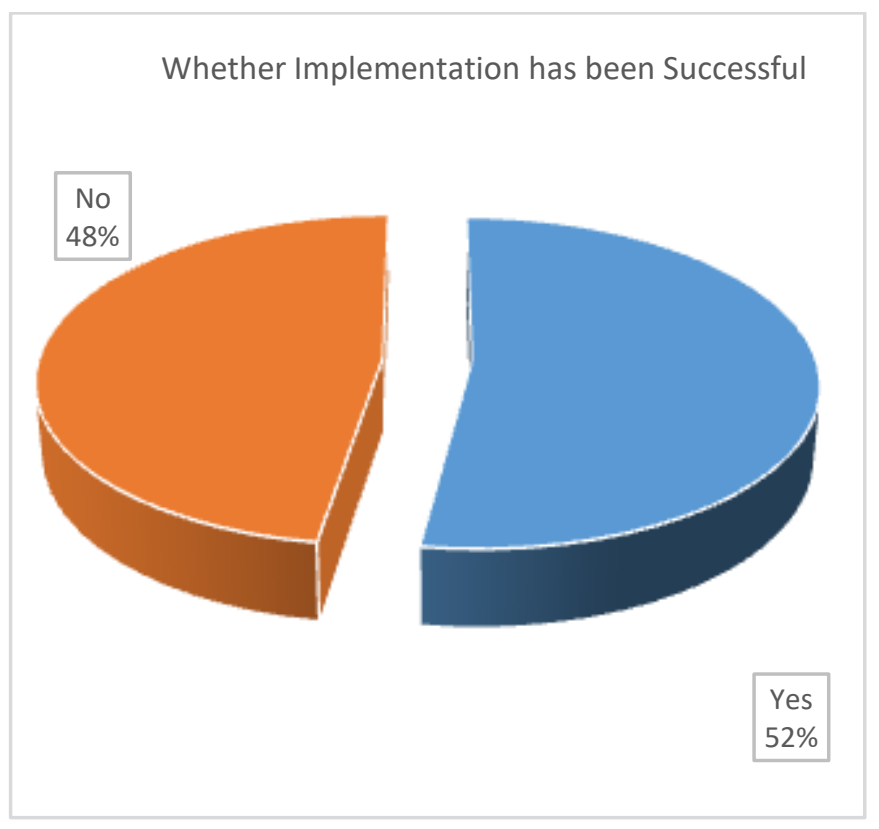

Figure 2: Whether Rights Protection has been Successful

Figure 4 above shows that most of those who are aware of the Remedial Policy feel there has been successful. However, $48 \%$ still feel there has not been an adequate implementation of the policy.

Asked whether they think the teacher should have an implementation role and the responses are as illustrated in the chart below.

\section{Whether Teacher has Implementation Role}

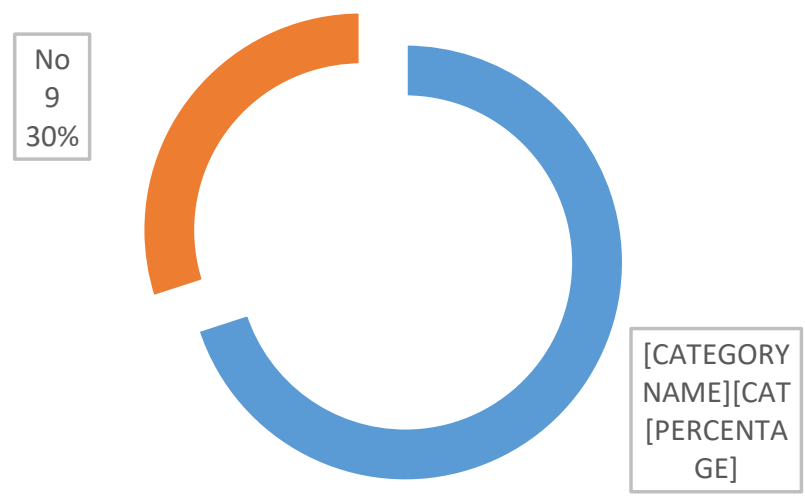

Figure 3: Whether the teacher has Implementation Role

As noted in figure 5 above, $70 \%$ of the teachers feel they have a role in implementing the remedial work policy. However, $30 \%$ thought they had no role in execution, which may be concluded that $30 \%$ are more likely to fail at implementation due to lack of knowledge of their role as an implementer. The $70 \%$ were explicitly asked what role they played, the respondents replied, and the table below gives the results.

Table 2: Role Played by Teacher

\begin{tabular}{|c|c|c|c|}
\hline Role Played by teacher & Freq. & Percent & Cum. \\
\hline Implementation & 2 & 9.09 & 9.09 \\
\hline Identification of slow learners & 2 & 9.09 & 18.18 \\
\hline Recommendations to School/Home & 2 & 9.09 & 27.27 \\
\hline Care and Support & 3 & 18.18 & 45.45 \\
\hline Liaison and motivation & 2 & 9.09 & 54.55 \\
\hline Monitoring and Evaluation & 4 & 27.27 & 81.82 \\
\hline Guidance and Counseling & 3 & 18.18 & 100.00 \\
\hline & & & \\
\hline Total & 22 & 100.00 & \\
\hline
\end{tabular}

As noted in table 14 above, most teachers cited monitoring and evaluation, guidance and counseling and care and support as their prominent implementation roles. Other roles included implementation, identification of slow learners, the recommendation to stakeholders and liaison and motivation. A follow-up question was posed on what specific strategies they employ in implementing remedial work policy; the teachers started the following, which is illustrated in the chart below. 


\section{Strategies Employed by teachers}

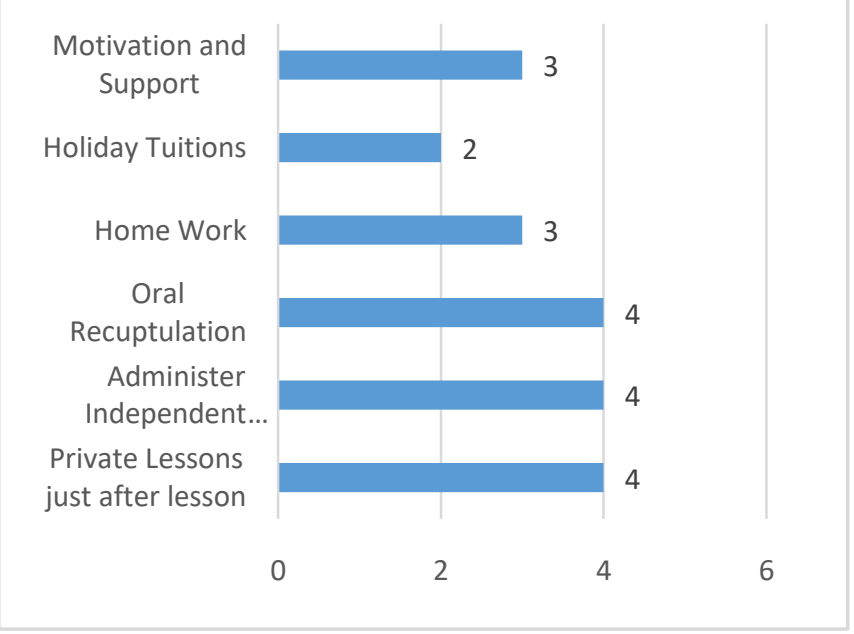

Figure 4: Remedial Strategies Employed by teachers

As evident in the chart above, there were three dominant strategies employed by teachers in remedial education, and these included Private Lessons, Independent Work and Oral Recapitulation. These were followed by homework and motivation and support, followed by holiday tuitions, respectively.

The research results showed that schools in Kasempa had oral recapitulation, independent work, and private lessons as the dominant strategies used in remedial work implementation, followed by homework, motivation, and support. Holiday tuition was the least used strategy. Although Zambia's National Assessment Survey Report (2013) records that schools with effective and well-coordinated Homework policy performed better, for example, the grant-aided schools, the schools in Kasempa District did not have homework as a dominant strategy for remedial work implementation. This was despite every school claiming that the homework policy was institutionalised and schedules were available. But physical inspection on Teachers' files and Learners' books revealed that homework was mostly uncoordinated and infrequently administered.

Independent work demanded that learners be given individualised attention. This strategy requires learners to be able to direct and supervise their learning. It requires teachers to localise the curriculum to meet the needs of individual learners. This is in line with Shield and Morgan (1998), who have asserted that localisation of the curriculum is critical in meeting learners' needs and motivating them to learn. Although this strategy would be very beneficial to Kasempa District's learners, only the lucky few could access it. Most teachers in the district were too overloaded with teaching periods to effectively implement independent work for a large group of learners. Thus, the most dominant remedial work implementation strategies in Kasempa District were unable to cater for the majority of the learners in need of remediation.

\section{Factors Affecting the Success of Remedial work}

We posed a question to those who believed they had no role in the current framework as to what role they should play, and their response is illustrated below.

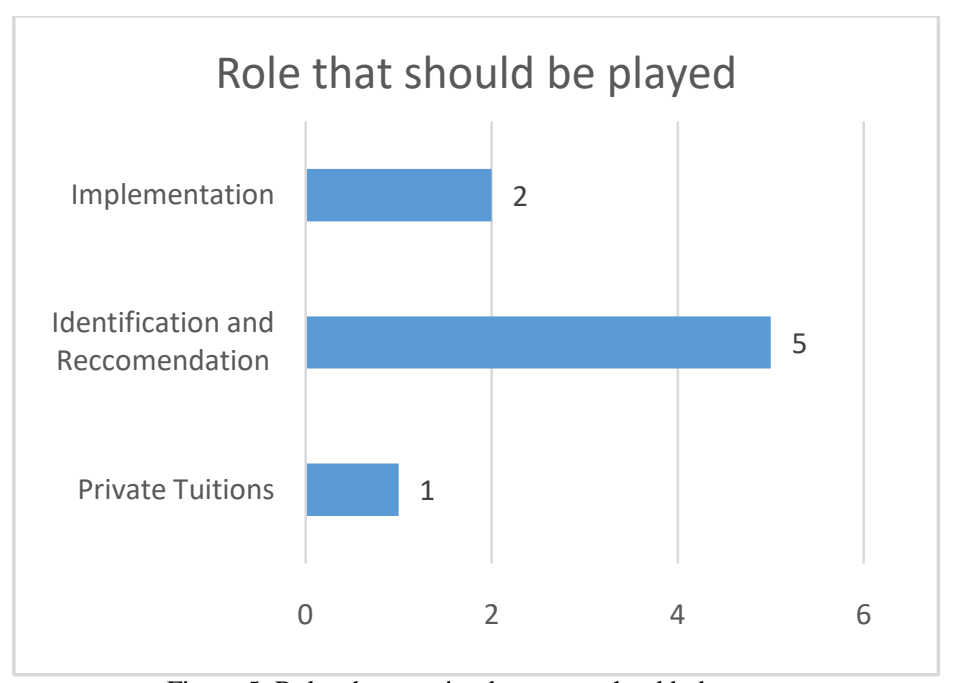

Figure 5: Roles that non-implementers should play

As noted above, the majority felt they should be empowered to identify remedial work needs and strategies and make necessary recommendations. One respondent went further to state that:

The problem with the current approach was that it was prescriptive with a "one-size-fits- all" approach, forgetting that remedial work needs differed in many different settings and contexts and various factors caused that slow learning; hence the need to "individualise" guidelines".

Asked why it was important for teachers to play a dominant role in implementing remedial education, respondents gave many different responses that were summarised and tabulated in the table below.

Table 3: Rationale for teacher dominance

\begin{tabular}{|c|c|c|c|}
\hline The rationale for teacher dominance & Freq. & Percent & Cum. \\
\hline & & & \\
\hline Empowers the Teacher & 3 & 16.67 & 16.67 \\
\hline Teachers are better placed & 5 & 27.78 & 44.44 \\
\hline Ensure easy collaboration & 4 & 22.22 & 66.67 \\
\hline Create Co-Responsibility & 4 & 22.22 & 88.89 \\
\hline Create Extra Income for Teachers & 2 & 11.11 & 100.00 \\
\hline & & & \\
\hline Total & 18 & 100.00 & \\
\hline
\end{tabular}

As noted in the table below, most teachers felt they were better placed as implementers, followed by those who thought it made collaboration more comfortable and created coresponsibility. Teachers were seen as being better placed by 
their role as educators, their direct link to the children and their accessibility to critical stakeholders such as administration, parents and peers. The latter point, thus, made co-responsibility easier. Others saw this as a means of empowerment and extra income for the teacher, where private tuitions were conducted. However, appointment here was also used to grant the teachers enough authority and autonomy to manage remedial education.

Table 4: Critical Players

\begin{tabular}{|c|c|c|c|}
\hline Three Critical Players & Freq. & Percent & Cum. \\
\hline & & & \\
\hline Teacher, School, Parent & 12 & 40.00 & 40.00 \\
\hline Teacher, Parent, Pupil & 6 & 20.00 & 60.00 \\
\hline School, Pupil, Parent & 2 & 6.67 & 66.67 \\
\hline PTA, Ministry, Pupil & 4 & 13.33 & 80.00 \\
\hline Ministry, School, Teacher & 4 & 13.33 & 93.33 \\
\hline Ministry, School, PTA & 2 & 6.67 & 100.00 \\
\hline & & & \\
\hline Total & 30 & 100.00 & \\
\hline
\end{tabular}

Asked who were the three most critical players in successful remedial education, $40 \%$ cited the teacher, the School and the Parent, followed by $20 \%$ who cited Teachers, parents and pupils. It is worth noting that a cumulative $73.33 \%$ cited teachers while $66.67 \%$ cited Parents and $66.67 \%$ also citing the school, followed by $33.33 \%$ who cited the ministry of education and another $33.33 \%$ who cited pupils and finally $6.67 \%$ who cited the PTA being the least mentioned.

Table 5: Key Remedial Features

\begin{tabular}{|l|l|}
\hline Key Remedial Features & $\%$ \\
\hline List of Pupils & $33.33 \%$ \\
\hline Remedial Time Table & $43.33 \%$ \\
\hline Remedial Policy & $13.33 \%$ \\
\hline Partner- Pupils & $10 \%$ \\
\hline Partner- Previous Teachers & $6.67 \%$ \\
\hline Partner Subject Teacher & $13.33 \%$ \\
\hline Partner Parent & $20 \%$ \\
\hline Partner Administrator & $23.33 \%$ \\
\hline
\end{tabular}

Teachers were asked if they had certain key features which were critical to successful implementation, and, unfortunately, as noted above, the majority did not have these key factors. Only 33.33\% had a list of Pupils needing remedial education. Hence only $33.33 \%$ identified remedial education needs. Planning was seen through the existence of a policy's timetable and existence, and only $43.33 \%$ had time tables, and only $13.33 \%$ had the policy. Hence there was no planning by the majority of teachers for remedial education. Partnerships and collaborations were also a key success feature of successful remedial education, however. Only 10\% had pupil/peer partners, only $6.67 \%$ had previous teachers as partners, only 13.335 had subject teachers as partners, only $20 \%$ had parents as partners, and only $23.33 \%$ had administrators as partners.

Asked as to rate the effectiveness of strategies recommended for effective remedial education, the respondents gave the ratings, and the following charts provide the outcome ratings:

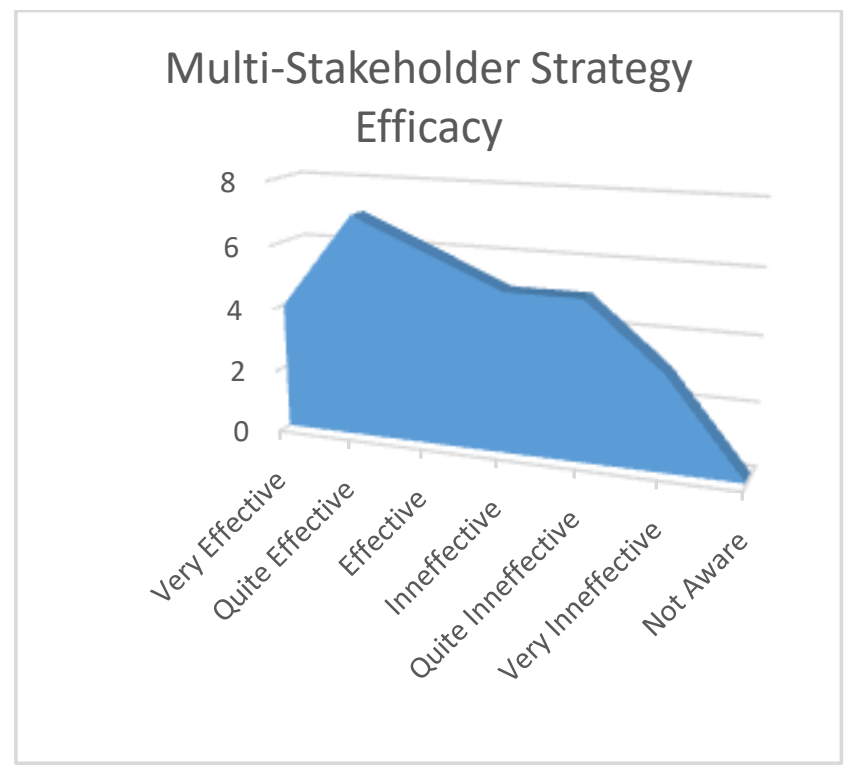

Figure 6: Multi-Stakeholder Strategy Efficacy

The efficacy of the multi-stakeholder strategy rating, as noted above, is skewed towards effectiveness; hence is seen as an effective strategy.

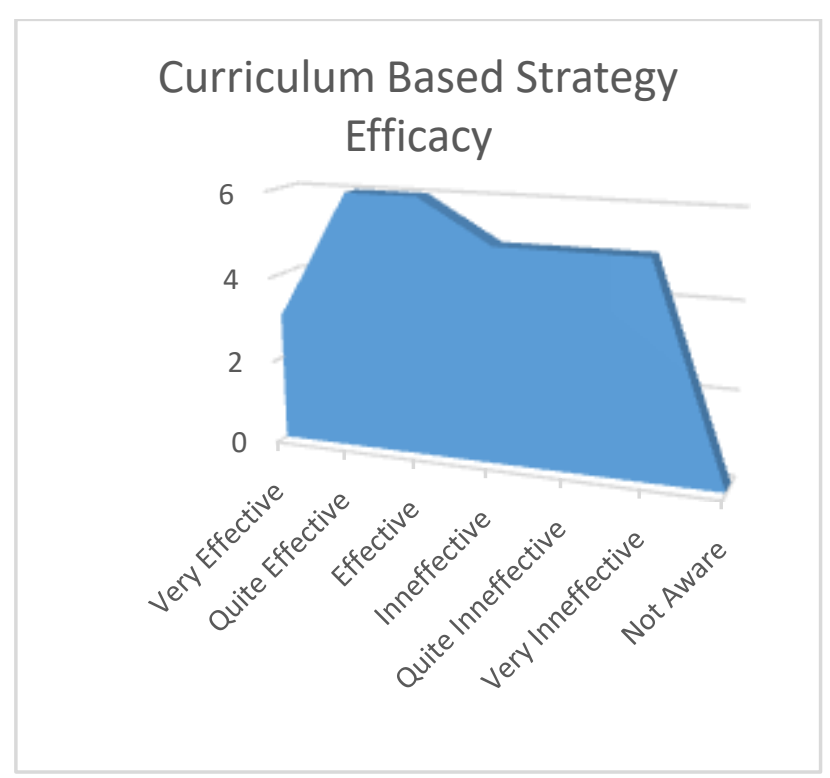

Figure 7: Curriculum-Based Strategy Efficacy

The chart above reveals that the ratings are skewed towards effectiveness; hence the curriculum-based strategy is effective. 


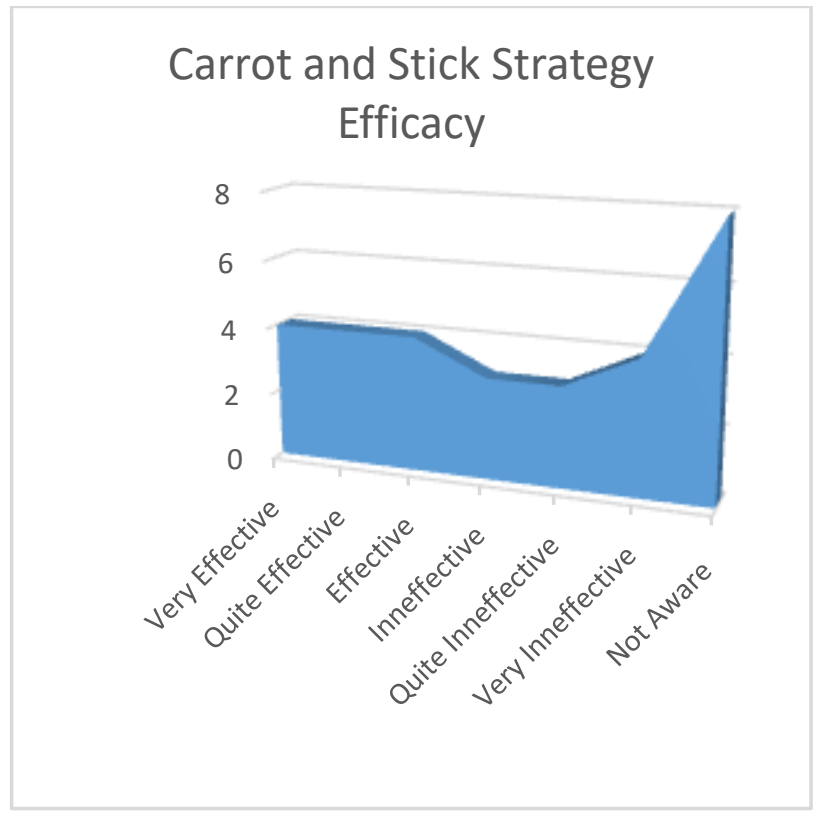

Figure 8: Carrot and Stick Strategy Efficacy

The chart above shows that while the ratings are skewed towards effectiveness, there is a very high level of lack of awareness of the approach.

\section{Reinforcement Strategy Efficacy}

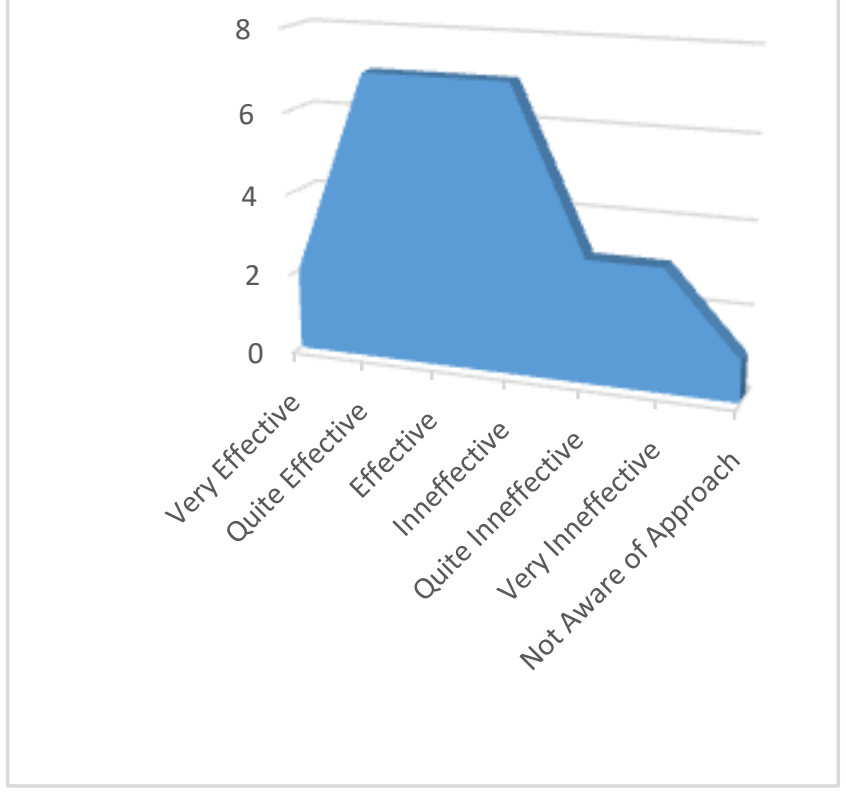

Figure 9: Reinforcement Strategy Efficacy

As noted in the area chart above, the ratings are skewed to effectiveness hence rated very useful.

\section{Self Motivation Strategy Efficacy}

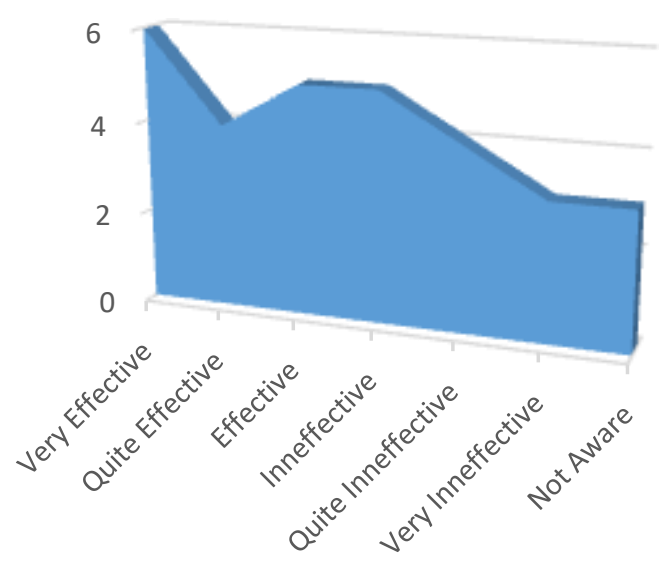

Figure 10: Self-Motivation Efficacy

The chart above shows the efficacy rating of self-motivation as a remedial education strategy. As noted above, the efficacy rating is more centrally distributed but with a bias towards effectiveness; hence can be deemed as a practical approach.

\section{Extra Curricular Strategy Efficacy}

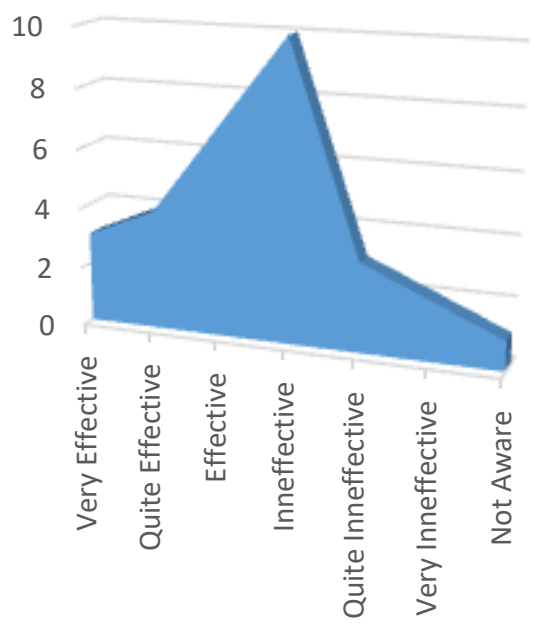

Figure 11: Extra-Curricular Strategy Efficacy

As evidenced in the chart above, the extra-curricular strategy was rated more ineffective than useful. On the other hand, as noted in the chart below, reading sessions have been placed very useful 


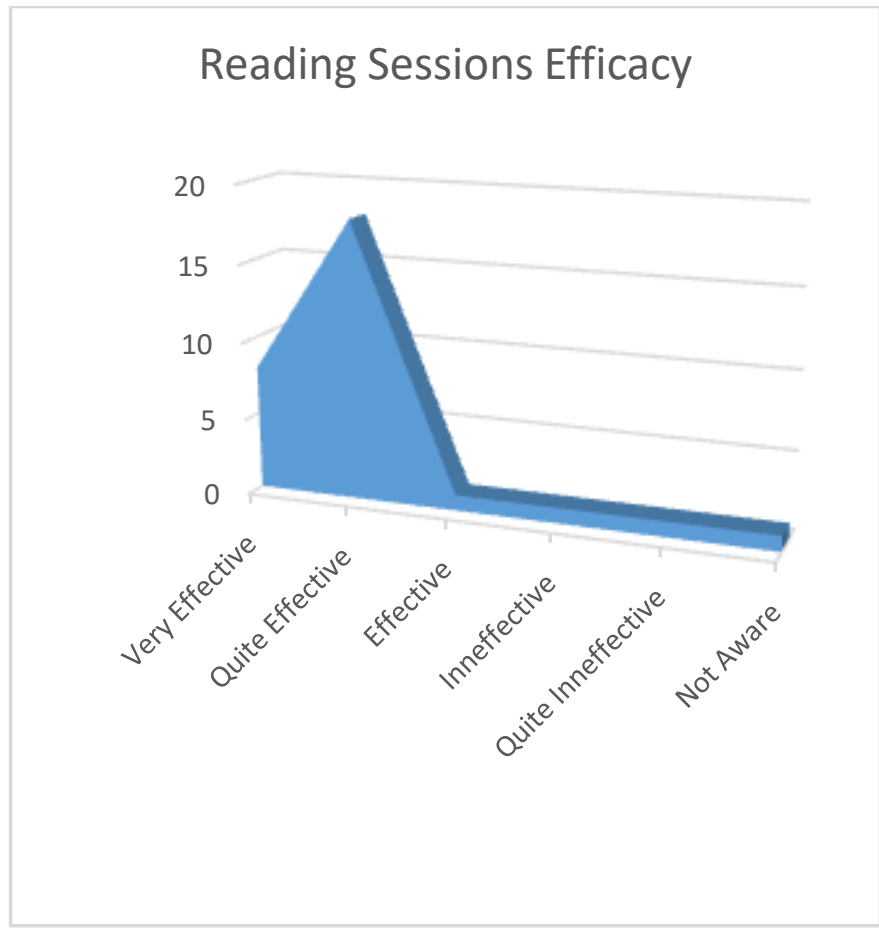

Figure 12: Reading Sessions Efficacy

Another evaluation was done in rating class exercises as a means of remedial education, and the chart below gives the outcome.

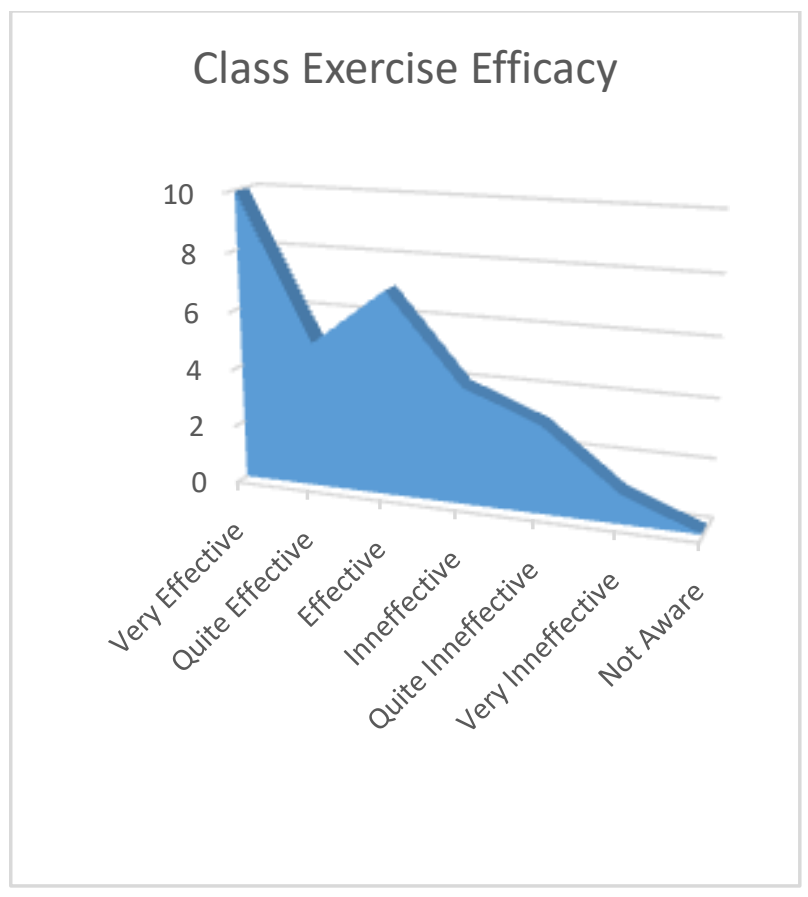

Figure 13: Class Exercise Efficacy

As clearly noted in the chart above, the ratings are skewed towards effectiveness; hence class exercise was an effective remedial strategy.

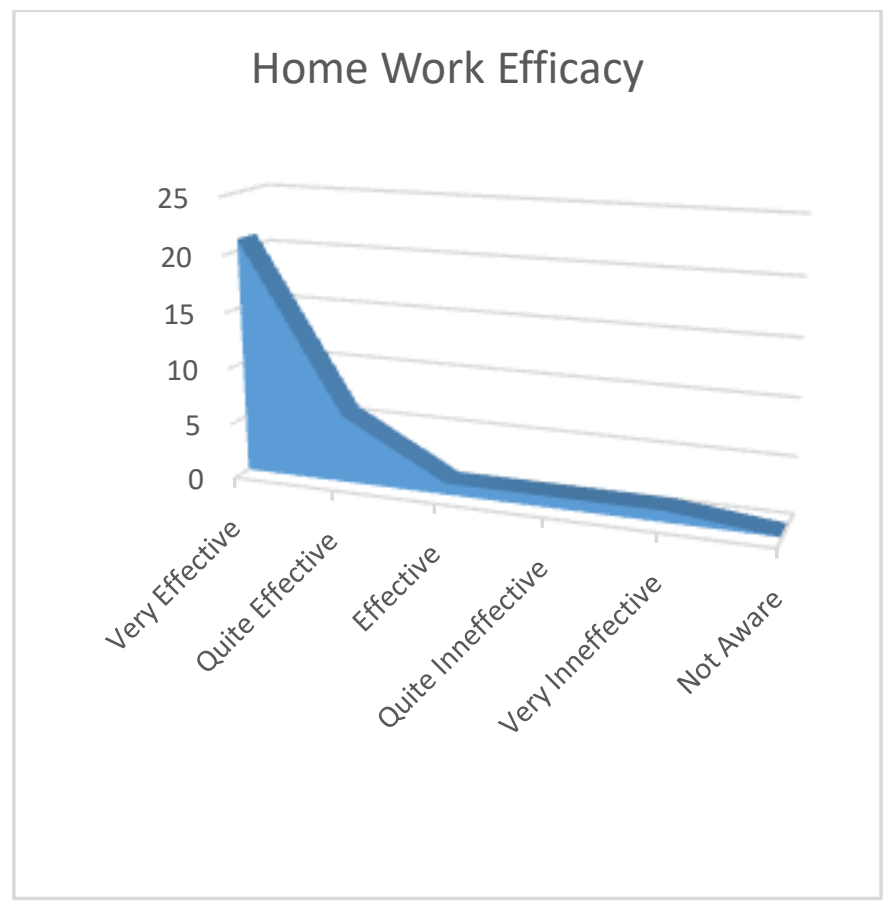

Figure 14: Homework Efficacy

As evident in the chart above, homework was rated as an effective remedial strategy.

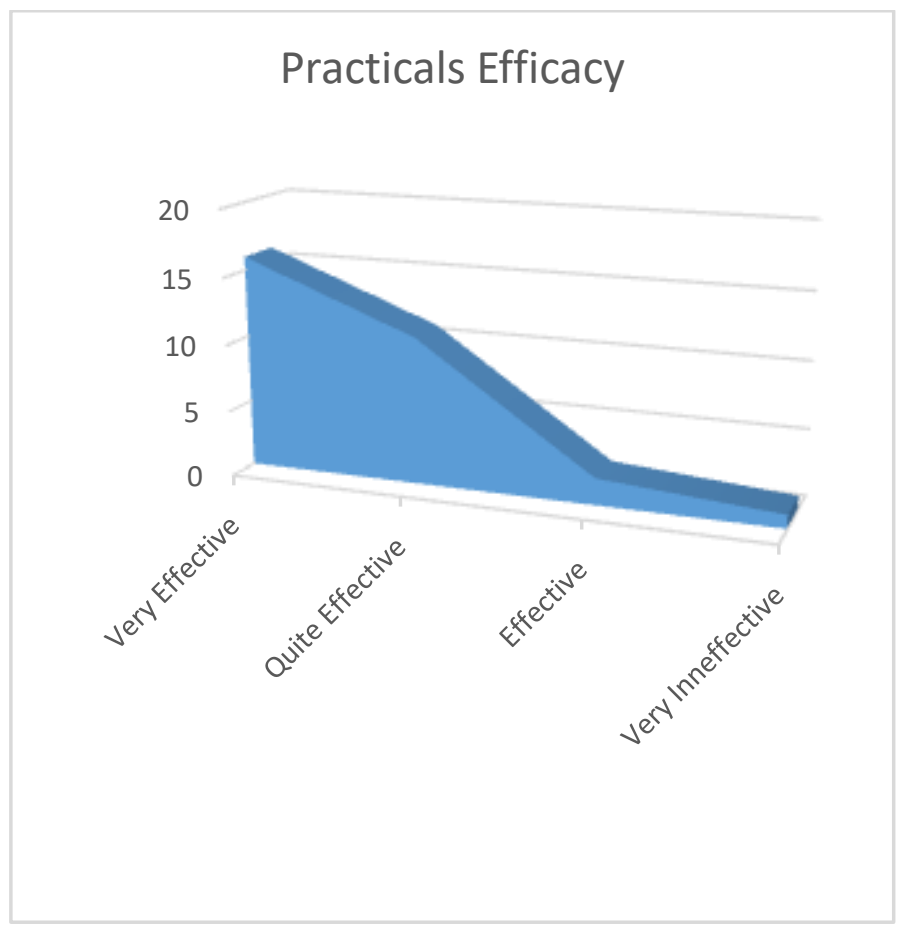

Figure 15: Practical Efficacy

As far as the efficacy of Practicals ratings were concerned, an overwhelming majority rated it with greater effectiveness, hence is an effective remedial strategy.

Teachers who believed they had no role to play in the current framework were asked what role they should play. The 
majority of them emphasised that they needed to be equipped with the knowledge and skills to identify remedial work needs. They also needed to possess strategies to make relevant recommendations. This agrees with Shield and Morgan (1998), who emphasise the need for the remedial teachers to have a strategy to conduct remedial work effectively. Although teachers were better placed to successfully implement remedial work in schools, their emphasis on empowerment was based on private tuitions where they would make extra money. The motivation here was personal gain rather than the benefit of the learners. Therefore, given the socio-economic status of Kasempa District, only a few learners in need of remedial work in Kasempa could afford to pay for private tuitions. This practice negatively affected the effectiveness of remedial work in the schools of the district.

The success of remedial work in schools requires concerted efforts of all stakeholders. Some critical players must work together to ensure that they get maximum benefits from the school activities, including remedial work. This is in line with the Social systems theory by Nurius (1983), which acknowledges remedial work as a complex phenomenon requiring multiple stakeholders to play various roles to ensure success. The findings revealed that teachers were the most critical players in ensuring the success of remedial work implementation, followed by the parents and the school. However, critical players must realise their various and respective roles in the performance of remedial work. The interaction of the external and internal forces is essential in the success of any policy. The parents must play a supportive role to their children and the school in ensuring that they can learn without any hindrance. The school must provide a conducive learning environment, plan and coordinate all academic programmes, including remedial work. The teacher needs to be at the centre of remedial work and employ various strategies to ensure successful corrective work implementation (Shield and Morgan, 1998).

In Kasempa, however, schools do not have adequate classroom accommodation and furniture. A large number of learners rent huts from surrounding villages and have to fend for them by doing piecework after school. There is no parental guidance. Most parents are peasant farmers who are semiliterate or illiterate and impoverished, unable to provide financial and academic support to their children. This is contrary to Topping and Wolfendale (1985), who asserts that parental involvement is necessary for their children's education. The evident lack of interaction among the key stakeholders like the teachers, parents and the school environment has created challenges for implementing remedial education.

To have strategies in place is one thing, and to have the practical techniques that yield desired results is another. The employed methods are factors that can influence the effectiveness of remedial work in schools. Some of the recommended strategies for remedial work were multistakeholder strategy, curriculum-based strategy, carrot and stick strategy and the reinforcement strategy. When the respondent teachers were asked to rate the effectiveness of the various recommended techniques, the findings showed that the multi-stakeholders force was skewed towards effectiveness. Partnership and collaboration are necessary for ensuring that remedial work succeeded. This is in line with Plowden (1967), who said the child's education was not only the school's responsibility, but that collaboration of stakeholders was required to influence the child's life. This showed that multi-stakeholder was an effective strategy. However, in Kasempa, there was very little collaboration between the teachers and the other important stakeholders. The lack of cooperation and partnership has negatively impacted remedial work effectiveness in secondary schools in Kasempa.

The research findings showed that the Carrot and Stick strategy rating was skewed towards effectiveness. This strategy uses reward and punishment as forms of motivation. Teachers could plan on appropriate tips for the learners committed to remedial lessons and punishment for those not committed to the programme. If the strategy was appropriately used in remedial education, it would be highly beneficial to the learners. It would contribute to the success of corrective work implementation in the district. However, there was a high level of lack of awareness of the approach among the teachers. And this means greatly affected the successful implementation of remedial education in the secondary schools of Kasempa. The findings of not having lists of learners in need of remedial work also made it impossible for teachers to know which learners needed rewards and who needed to be punished. Thus the ignorance on how to use the carrot and stick approach and the general lack of preparedness by most teachers negatively affected the implementation of remedial work in Kasempa.

\section{Challenges Affecting Remedial work}

Many factors affect the successful implementation of remedial work in the secondary schools of Kasempa. The research findings revealed that administrative efficiency had a very high impact on the performance of remedial work. The higher the organisational efficiency present in the school, the higher the effectiveness of the implementation of remedial education. Administrative efficiency is necessary for the successful implementation of any programme because it entails prudent utilisation of resources to achieve the set goals. The opposite was also the case: administrative inefficiency was a factor that resulted in the unsuccessful implementation of programmes. Although remedial education is critical in raising schools' academic performance, school authorities did not prioritise the meagre resources' apportionment. This negatively affected the successful implementation of remedial work in Kasempa.

The other important factor influencing the successful implementation of remedial education in secondary schools of Kasempa was administrative effectiveness. While organisational efficiency deals with school authorities' ability 
to achieve maximum results from minimal resources, managerial effectiveness tackles the school authorities' capacity to actualise the set goals. The findings in Kasempa showed that there was administrative ineffectiveness in the secondary schools to the effect that the school authorities did not monitor and evaluate remedial work implementation. Teachers felt unsupported by their respective school administrators, who seemed detached from remedial work activities. The lack of collaboration with teachers and failure to support and monitor what the teachers were doing was typical administrative ineffectiveness which negatively affected remedial work implementation.

Remedial education was about identifying pupils' learning deficiencies, correcting them, and building their capacities to learn better. Thus, for remedial work implementation to succeed there was a need to provide early intervention to the learners to correct the identified learning deficiencies. The findings were in line with Marshal and Weinstein (1984) and Johnson and Afflerbach (1985), who has said that the objectives of remedial work are to solve doubts of students timely, to solve problems that arise during teaching, to develop good tendencies among students to overcome deficiencies in work. The research results showed that early intervention was a high impact factor in the implementation of remedial work. But the fact that teachers were not having on their files key features like lists of learners in need of remediation, remedial time-tables were enough revelation that little intervention was planned for the deficient learners in secondary schools of Kasempa. The majority of the learners in need of remedial lessons were missing remedial work, so no intervention took place in most of them. This negatively affected the effectiveness of remedial work in the secondary schools of Kasempa.

Most parents in Kasempa were not deeply involved in their children's education, as revealed by the study. Many pupils lacked parental guidance and involvement in their education as learners stayed in rented huts far away from their parents. Parents' failure to interact with teachers and resolve teachers' concerns about the pupils when summoned also shows that the learners do not receive support from the parents. Teachers reported that most parents don't meet school authorities to resolve the practical challenges when called for either money or any other school-related issues. Many parents did not pay fees for their children, making them look for piecework to raise funds for their school. Thus, many learners are just by themselves and lack parental involvement in their education.

\section{V.CONCLUSION}

The study discovered that many factors negatively affected the effectiveness of remedial work policy in the secondary schools of Kasempa. The elements could be categorised as being both internal and external to the school environment. The internal factors included teacher awareness of the Remedial policy, remedial methods used by teachers, teacher preparedness, headteachers' support for remedial education and school infrastructure. The external factors included parental monitoring of learners' schoolwork, parental guidance, learners' home environment and parental support to learners' education.

The study also revealed that not all teachers understood remedial policy, and as a result, they were unable to implement it successfully. The majority of the teachers who were aware of the remedial policy did not adequately prepare for its effective implementation. The findings showed that the most used curative work method was private tuition, which most learners in need of remedial education could not attend as they had no money which they were asked to pay. Lack of adequate teacher preparedness was revealed by the absence of remedial time tables and lists of the identified learners in need of remediation.

Of the several remedial work implementation strategies, three were found to be dominant. These were private lessons, independent work and oral recapitulation. But the most preferred by teachers was private tuition, which empowered teachers with extra income. However, many learners were not able to bear the cost. Independent work required a lot of support from both teachers and parents. Still, the study showed that the majority of learners in need of remedial work did not have a supportive home environment.

\section{RECOMMENDATIONS}

In light of the study findings, the data analysis, discussion and conclusion, this study made recommendations for action and further research suggestions.

1. The government must socialise all stakeholders to improve support for the learners, especially in rural areas.

2. The government must improve school infrastructure in rural areas by renovating old schools and adding to classroom space to have room for remedial education.

3. The government and Education Boards must take practical measures to make it mandatory for teachers to conduct remedial work in all public schools.

4. The government must intentionally create conducive working conditions for teachers by providing reasonably good salaries to focus on delivering free remedial work instead of asking learners to pay for private tuitions.

\section{REFERENCES}

[1] Afflerbach, P. (1990). The influence of prior knowledge and text genre on readers' prediction strategies. Journal of Reading Behavior, 22(2), 131-148

[2] Bullock, J.E. (1975). Critical issues in special and remedial education. Boston: Houghton Mifflin.

[3] Chikwature, W and Oyedele, V. (2016). The impact of remediation in the teaching and learning of map work in geography subject at ZJC level: A case of Marange high school. European Journal of Research and Reflections in Educational Services, 4,(5),30-45. 
[4] Chipindi, F. M. (2009). The quality-quantity trade-off: Implications of expanded enrolments at two of Zambia's public universities (Unpublished master's dissertation). University of Zambia, Lusaka.

[5] Chipindi, F.M. (2017). Neoliberal governmentality, responsibilisation and the deepening of academic tribalism in the Zambian academy: A commentary. International Journal of MultiDisciplinary Research. ISBN (online): 3471-7102.

[6] Chipindi, F.M. (2018). Negotiating professional identities in a liberalised Sub-Saharan economy: A case of university of Zambia faculty (unpublished $\mathrm{PhD}$ dissertation). University of Minnesota, Minneapolis.

[7] Chipindi, F.M. \& Doyle, H. (2017). Zambia scoping study. In H. Doyle, A.M. Barrett \& A. Reeves (Eds.), Improving the quality of teaching in secondary education: scoping studies for Zambia, Malawi, Tanzania, Côte D'Ivoire and Senegal (pp. 4-32). Bristol: Bristol University.

[8] Chipindi, F.M. \& Chipindi, S.J. (2016). Trade-off issues in teacher education at the university of Zambia: Growing student numbers and the quality of teacher education processes. International Journal of Teaching and Learning in Africa 3(1), 82-86.

[9] Chipindi, F.M. \& Vavrus, F. (2018). The ontology of mention: Contexts, contests, and constructs of academic identity among university of Zambia faculty. FIRE: Forum for International Research in Education, 4, (3), 102-116. ISSN: 2326-3873.

[10] Cohen, L., Manion, L. and Morrison, K. (2000) Research methods in education. London: Routledge Falmer.

[11] Daka, H. (2019). Perspectives on course management, teaching and assessment of undergraduate programmes at the medical school of the University of Zambia, PhD Thesis. The University of Zambia.

[12] Daka, H., Chipindi, F.M. \& Mwale-Mkandawire, M. (2020). The relationship between assessment practices and students' academic performances. A case of undergraduate students at the medical school of the university of Zambia, 2008 - 2016. Zambian Journal of Educational Management, Administration and Leadership, 1, (1), 143-156. ISSN: 2706-7416 (Print).

[13] Daka, H., Sekelani, S. S. \& Namafe, C. M. (2017). Course management, teaching and assessing undergraduates at the medical school of the University of Zambia. International Journal of Humanities Social Sciences and Education, 4 (10), 10-18.

[14] Daka H, Jacob W J, Kakupa P, Mwelwa K (2017). Theuse of social networks in curbing HIV in higher educationinstitutions: A case study of the Universityof Zambia. World Journal of AIDS, 7, 22-137.

[15] Douglas, J.W.B. (1964). Thehome and the school. London: MacGibbon and Kee.

[16] Hambulo, F. \&Mukalula-Kalumbi, M. (2017). The negative effects of social and educational policy changes on the religious mission of catholic secondary schooling in Zambia's southern province: A historical analytical perspective from 1964 to date. International Journal of Humanities Social Sciences and Education, 4 (7), PP 39-48. ISSN 2349-0373 (Print) \& ISSN 2349-0381 (Online) http://dx.doi.org/10.20431/23490381.0407006

[17] Her Majesty's Stationery Office (1967). Plowden report. London: HMSO.

[18] Her Majesty Stationery Office (1977). Report of the committee of inquiry into management and government of schools. London: HMSO.

[19] Hewison, J. (1981). Parental involvement in reading achievement. London: Routledge.

[20] McEwin, C.K. \& Greene, M.W. (2010). Results and recommendations from the 2009 national surveys of randomly selected and highly successful middle-level schools. Middle School Journal, 42 (1), 49-63

[21] Levpušček, M., \&Zupančič, M. (2009). Math achievement in early adolescence: The role of parental involvement, teachers' behaviour, and students' motivational beliefs about math. Journal of Early Adolescence, 29, 541-570.

[22] Manchishi, P.C., and W. Hamweete (2017). Education inthe first republic: Rationale and focus. In G. Masaiti (Ed.).Education in Zambia at 50 years of independence and beyond. Lusaka: Unzapress.

[23] MESVTEE. (2013). The Zambia education curriculum framework. Lusaka: Government Printers.

[24] Mpolomoka, D.L, Kanduza, E., Sichali, C, Sampa, P and Hamweete, W. (2016). Guidance and counselling internship experiences of odl students in Zambia. International Open and Distance Learning Journal (Teacher Development)3, (1), 38-47.

[25] Moonga, A.L.H, Changala, M and Lisulo, S. (2018). Development of Education in the Third Republic: Policies and Implications. In: Massaiti, G., Education in Zambia at Fifty Years of Independence and Beyond: History, current Status and Contemporary Issues. UNZA Press. Pp. 24-35.

[26] Msango, J.H., Luchembe, M., Changala, M,. Lisulo, S. and Moonga, A.L.H. (2015). Innovations in educational assessment in Africa: The case of the Zambian secondary school sector. [online]. Available from: www.scholar.google.com. [Accessed: 20 February, 2021]

[27] Mukalula-Kalumbi, M. (2015). Hiv and aids workplace policy: An implementation assessment of strategies in selected secondary schools of Lusaka and Northern provinces.Zambia Journal of Education, 4(2), 26 - 35

[28] Mukalula-Kalumbi, M. (2020). Management of teaching experience at school level and linkage with knowledge perceptions in basic language constructs among early childhood educationpreservice teachers. Zambian Journal of Educational Management, Administration and Leadership, 1 (1), 107-124.

[29] Mwale-Mkandawire Margaret. (2019). Current trends in gender issues in education. Lusaka: UNZA Press.

[30] Nurius, Paula S. (1983). Mental health implications of sexual orientation. The Journal of Sex Research, 19, (2), 119-136.

[31] Preece, J., Rogers, Y., \& Sharp, H. (2002). Interaction design: Beyond human-computer interaction. New York, NY: John Wiley \& Sons.

[32] Shield, G and Morgan, M. (1998). Study of remedial education in Irish primary schools. Dublin: Education Resource Centre.

[33] Silva, C.D and Capellin, S.A. (2010). Efficacy of the reading and phonological remediation programme in learning disabilities. Pro Fono, 22, (2), 131-139.

[34] Smith, P. (1987). Parents and teachers together. London: MacMillan Education.

[35] Swarup, S and Mehta, D.H. (2011). Manual of the diagnostic test of learning disability. New Delhi: Prasad Psycho Corporation.

[36] Thomas, M. A.M., Serenje-Chipindi, J \& Chipindi, F.M. (2020), Comparing course syllabi from A to Z: Examining the contexts, content, and concerns for social foundations of education in Australia and Zambia. In A. E. Mazawi \& M. Stack (Eds.). Course syllabi in faculties of education across the world: Bodies of knowledge and their discontents (pp 38-50). Sydney: Bloomsbury, ISBN 978-1-3500-9425-3 (hardback) 978-1-35009427-7 (online).

[37] Yin, K. R. (2003). Case study research: design and methods. London: Sage Publication.

[38] Welman, J. and Kruger, S. (2001). Research methodology. Cape Town: Oxford University Press. 